\title{
Arka pamięci? Kilka uwag na marginesie filmów Aleksandra Sokurowa Rosyjska arka i Frankofonia
}

\section{Ark of memory? Some notes on the margin of the movies of Alexander Sokurov's Russian Ark and Francofonia}

\begin{abstract}
Alexander Sokurov is considered to be a creator who often attempts to settle with the uncomfortable past, at the same time revealing the mechanisms of the functioning of power and politics, including the policy of remembrance. The Russian Ark (2002) and Francofonia (2015), which divides over a dozen years and which seemingly concern two different countries and situations, are no different in this respect. And yet, using the same motif in them, i.e. the motif of the museum, Sokurov in Francofonia returns to events that he could not, for various reasons, deal with in a prior movie. We mean here the role of museums, "silent" witnesses of history. The evacuation of works of art from the Hermitage and the Louvre during the war is a source of pride and an element of the victorious narrative, but in the case of Hermitage it is impossible not to think about the price that the city and its inhabitants paid during their siege. They could not be evacuated as efficiently as the museum collections. And thus the idea of saving valuable works of the Hermitage will be invariably associated with the inept evacuation of the people of Leningrad. And it must be admitted that this is not the first opportunity when it comes to Sokurov to remind the world of the painful wound inflicted on the city of Neva and its inhabitants, not only by the Germans, but also to ask about the price of survival.
\end{abstract}

Keywords: Sokurov, memory, contemporary Russian cinema, Russian Ark, Francofonia

Beata Pawletko, Uniwersytet Śląski w Katowicach, Sosnowiec - Polska, beata.pawletko@us.edu.pl, ORCID ID: https://orcid.org/0000-0002-1430-1547

Aleksander Sokurow uchodzi za twórcę, który często podejmuje próby rozliczenia z niewygodną przeszłością, a przy tym obnaża mechanizmy funkcjonowania władzy i polityki, w tym polityki historycznej. Interesujące dla niego są zwłaszcza przemilczenia, pominięcia w obrębie rosyjskiej polityki pamięci i oficjalnych praktyk upamiętniania. Jak zauważa Kiriłł Ass:

При взгляде на его фильмографию складывается впечатление, что он торопится вспомнить и осмыслить все главные умолчания русской истории двадцатого века и исследовать все 
тщательно избегаемые уголки русской душевной жизни. В ряду этих умолчаний Блокада Ленинграда остается все еще не понятой в полной мере частью нашей истории (Ass, źródło elektroniczne).

Ten nurt rozrachunkowy w twórczości Sokurowa zdecydowanie nasilił się już w nowym stuleciu (Wojnicka 410). Tekst Assa dotyczy konkretnie filmu Czytając „Księge blokady” (Читаем „Блокадную книгу”, 2009), jednak strategia upamiętnienia oblężenia Leningradu jako ważnego, choć niewygodnego dla władzy wydarzenia obejmuje nie tylko ten konkretny obraz. Czytając „Księge blokady” to najbardziej znana i kompletna wypowiedź reżysera na temat bolesnej rany zadanej miastu nad Newą podczas Wielkiej Wojny Ojczyźnianej i ukłon w stronę Księgi blokady Alesia Adamowicza i Daniiła Granina. Przy okazji warto podkreślić, że książka Adamowicza i Granina ma za sobą długą i wyboistą drogę wiodącą do publikacji pełnej, nieocenzurowanej wersji, która ukazała się dopiero w 2013 roku. Na uznanie zasługuje zwłaszcza fakt, że hołd oblężonym składają mieszkańcy miasta $\mathrm{w}$ różnym wieku i różnych profesji, zaś siła tego obrazu tkwi w „nieprzygotowaniu” aktorów (również tych profesjonalnych) na to, co przyjdzie im przeczytać, z jakimi emocjami będą musieli się zmierzyć i to bez dubli, bez prób. Nic dziwnego, że film został oceniony bardzo wysoko zarówno przez rodzimych, jak i zagranicznych odbiorców, choć nie można zapominać, że jest to dokument telewizyjny, stąd zapewne decyzja Sokurowa, by narrację dotyczącą oblężenia wplatać i w inne filmy. Ostatnio wątek ten pojawił się w obrazie Frankofonia (Франкофония), który swoją premierę miał w 2015 roku i pozornie dotyczy innej, chociaż w wielu punktach zbieżnej rzeczywistości. Reżyser wykorzystuje tutaj luźną, mozaikową kompozycję, na którą składają się archiwalne kroniki i zdjęcia, przeplatane fragmentami dokumentalno-fabularnymi. Wszystko po to, by opowiadając o Luwrze i jego wojennych dziejach, w dość nieoczywisty sposób wspomnieć o tragedii oblężonego Leningradu. Decyzja ta ma tym większe uzasadnienie, że wyżej wymieniony film z racji poruszanego wątku należy do najbardziej rozpoznawalnych w twórczości Sokurowa, a to przekłada się na szerszy, międzynarodowy odbiór oraz większą szansę na kształtowanie pamięci zbiorowej, bowiem, jak zauważa Magdalena Saryusz-Wolska,

za kształtowanie pamięci zbiorowej odpowiadają głównie te tytuły, które z różnych powodów odbiły się głośnym echem nie tylko w wąskim świecie znawców tematu. Prawdopodobnie choć dla pełnego potwierdzenia tej tezy trzeba by przeprowadzić rzetelne badania - znane książki i filmy znacznie silniej wpływają na zbiorowe wyobrażenia o przeszłości niż elitarny dyskurs historyków, politologów czy socjologów (Saryusz-Wolska 222).

Warto zwrócić uwagę, że jako pretekst do poruszania zagadnień związanych z oblężonym Leningradem posłużyły filmy, w których dominantą jest temat mu- 
zeum i roli sztuki w życiu człowieka. Tak dzieje się zarówno w przypadku Rosyjskiej arki (Русский ковчег, 2002) - najbardziej znanego filmu w dorobku Sokurowa, powstałego w związku z obchodami trzechsetlecia założenia Petersburga - jak i wspomnianej Frankofonii. Trzeba przyznać, że wątek ten przewija się właściwie przez całą twórczość Sokurowa. Nie bez znaczenia dla takiego widzenia muzeum jako ostoi pamięci, ciągłości kulturowej jest jego własna biografia. Rafał Syska mówi o utraconej tożsamości reżysera, co na przełomie lat 80. i 90. XX wieku przełożyło się w jego twórczości na stale obecny motyw odzyskiwania pamięci narodowej, tożsamości, dumy (Syska 2014: 313). Chodzi tu bezpośrednio o jego miejsce narodzin, czyli syberyjską wieś, zalaną przez wody zapory, która tu powstała. A zatem nie ma śladu, żadnych pozostałości materialnych po miejscu urodzenia, podobnie jak nie ma jednego miejsca utożsamianego z dzieciństwem, przestrzeni oswojonej. To z kolei związane jest z ciągłymi przenosinami rodziny Sokurowów, wymuszonymi przez zawód ojca, oficera Armii Czerwonej. Na jego drodze życiowej pojawią się tak odległe kulturowo miejsca jak m.in. Polska i Turkmenia. Nic dziwnego zatem, że Syska pisze o człowieku odciętym od korzeni, niezakotwiczonym w żadnym konkretnym miejscu:

Sokurow przyszedł na świat w 1951 roku na dalekiej Syberii w niewielkiej Podorwice - miejscowości, która dziś już nie istnieje, zalana wraz z domami, cerkwią, cmentarzami i pamięcią po przodkach przez wody zapory. To wydarzenie stało się konstytutywnym dla Sokurowa doświadczeniem egzystencjalnym, dla człowieka odciętego od korzeni, pozbawionego tożsamości definiowanej przez rodzinne miasto i poszerzane w dzieciństwie przestrzenie (Syska 2013: 364).

Być może to właśnie spowodowało, że Sokurow jest w szczególny sposób „przewrażliwiony” na punkcie sztuki, rozumianej w kategoriach dziedzictwa narodowego i kulturowego. W dorosłym życiu jego domem stało się miasto nad Newą, a największe znaczenie w tym domu, co autor Cielca (Телеu, 2001) podkreśla w wielu wywiadach, miał właśnie Ermitaż. Jednocześnie ciągłe przemieszczanie się z miejsca na miejsce $\mathrm{w}$ dzieciństwie spowodowało niezgodę reżysera na propozycję swojego mentora, Andrieja Tarkowskiego, by - podobnie jak on wyemigrować. W biografii Sokurowa odnajdujemy zatem wszystkie wymienione przez Barbarę Skargę rodzaje śladów-odcisków, tj. piętno, bliznę i wezwanie (cyt. za: Saryusz-Wolska 212-215). Piętnem byłoby wymuszone przez okoliczności wykorzenienie i utrata domu, blizną przedłużająca się „,bezdomność”, zaś wezwaniem podejmowanie bolesnych, trudnych wątków związanych z oswojonym nowym miejscem. W przypadku Sokurowa będzie to z jednej strony zwrot ku przeszłości Petersburga i próba nieustannego upominania się o godne upamiętnianie ofiar blokady, podążanie śladami ich doświadczeń, z drugiej strony to ochrona zabytków (Kantor, źródło elekroniczne). Według reżysera muzea to miejsca ważne 
z punktu widzenia kształtowania i ciągłości pamięci kulturowej, która - zgodnie z koncepcją Aleidy Assmann - przekazywana w formie materialnej, jest w stanie przetrwać wiele pokoleń, wykracza bowiem ponad polityczne interesy. Jej odwrotnością, zdaniem Assmann, jest z kolei pamięć zbiorowa, narodowa, podporządkowana celom politycznym i nierzadko ideologicznym (Assmann 315-316). Egzemplifikacją takiego sposobu myślenia jest w twórczości Sokurowa film Kamień (Камень) z 1992 roku. Jego bohaterem jest Anton Czechow, a oś fabuły stanowi wizyta w domu-muzeum, czyli Białej Daczy mieszczącej się w Jałcie. Odwiedza ją już po śmierci jako duch (ten sam motyw pojawi się we Frankofonii), choć jego zachowanie mogłoby wskazywać, że wciąż żyje. Na marginesie tej filmowej opowieści o samotności, kwestiach pamięci i zapomnienia warto odnotować wątek polityczny. Mieszanie się polityki do spraw kultury, a zwłaszcza dziedzictwa kulturowego, bez dbałości o zachowanie dóbr, nienależących przecież do konkretnego władcy, przywódcy, jest, zdaniem Sokurowa, działaniem pozbawionym wrażliwości i wyobraźni, a nade wszystko niezmiernie krótkowzrocznym, które z biegiem czasu może obrócić się przeciwko społeczeństwu reprezentowanemu przez tego człowieka. W filmie Kamień będzie to odzyskujący swą niepodległość naród ukraiński. Jak pisze Syska:

\begin{abstract}
Sokurow przybył do jałtańskiej „Białej Daczy” Czechowa, gdy sytuacja muzeum stała się przyczyną międzynarodowego sporu. Władze ukraińskie nie widziały potrzeby finansowania pamiątek po rosyjskim pisarzu, zwłaszcza że na przełomie dekad ukraińska przyszłość Krymu nie była nadto oczywista. Pogarszający się stan pałacyku Czechowa wzbudził jednak międzynarodowy ferment, powołano nawet fundację zasilaną przez fundusze gwiazd angielskiej sceny i podjęto decyzję o restauracji budynku (Syska 2014: 314).
\end{abstract}

We Frankofonii refleksja dotycząca ścisłych powiązań między władzą a sztuką zogniskowana jest wokół karykaturalnie przedstawionej postaci Napoleona Bonapartego, wędrującego jako duch wraz z uosobieniem Republiki Francuskiej, czyli Marianną, nocą po opustoszałych salach Luwru. Przerysowaniu ulega ego władcy, powtarzającego przed każdym oglądanym obrazem (z Mona Lisa Leonarda da Vinci włącznie) właściwie jedną, jedyną frazę: „To ja”. Nie należy przy tym zapominać, że chociaż postać cesarza nie pojawia się tu przypadkowo, wszak ocena postaci Napoleona przez Sokurowa jest negatywna (Koreckij, źródło elektroniczne), to Bonaparte pozostaje tak naprawdę symbolem tych wszystkich „krótkowzrocznych” władców i przywódców, którzy z jednej strony przypisują sobie zasługi na polu krzewienia kultury, wspierają twórców, szczycą się tym, że tworzą lub rozbudowują kolekcje muzealne, ale z drugiej strony zdobyte przez nich dzieła sztuki to często trofea i łupy wojenne lub efekt grabieży. A na dodatek interpretacja zdobytych często w niechlubny sposób dzieł sztuki bardzo często sprowadza się do narcystycznego przeglądania się w nich niby w lustrze, bez 
głębszej refleksji na temat tego, co znajduje się na tym czy innym obrazie. Poza zainteresowaniem władców pozostają natomiast wskazówki wysyłane przez autorów, zawarte w ich twórczości. To dlatego w swoim filmie Sokurow ironicznie pyta, czy cesarze znają się na sztuce i gorzko konstatuje, że cele państwa i twórców rzadko bywają zbieżne, a to niestety przynosi szkody nie tylko artystom, ale i odbiorcom.

We Frankofonii bez trudu odnajdujemy nawiązania do wcześniejszych filmów reżysera - np. do wspomnianego już obrazu Kamień i jego bohatera, tj. Antona Czechowa, który wraz z hrabią Lwem Tołstojem pojawia się właściwie już na początku, w pierwszych kadrach Frankofonii. W ten sposób Sokurow akcentuje wielkie znaczenie sztuki i literatury w życiu każdego człowieka, ich profetyczną rolę wynikającą z niezwykłego daru widzenia i przenikania rzeczywistości i człowieka na wskroś, tj. daru, jaki mają wielcy mistrzowie słowa i obrazu. Dość często Sokurow podkreśla przepaść między wagą, doniosłością dokonań w sferze literatury i sztuki a poziomem współczesnej kinematografii (Kičin, źródło elektroniczne). Efektem takiego spojrzenia jest syntetyzujące, zuniwersalizowane przesłanie. Oprócz tego warto wymienić za krytykiem filmowym i dziennikarzem Antonem Dolinem jeszcze inne konotacje, a mianowicie związane z filmem Elegia drogi (Элегия дороги) z 2001 roku. Tam również mieliśmy do czynienia z wizytą w muzeum, tym razem w Rotterdamie, i obcowaniem ze sztuką. Co ciekawe, szacunek do dzieł sztuki manifestowany jest w filmach Sokurowa poprzez niespieszną ich kontemplację, co we Frankofonii sygnalizowane jest przez niezwykłe zbliżenia oglądanych dzieł (szczególnie portretów), możliwe dzięki doskonałej pracy operatora, którym był Bruno Delbonnel - autor zdjęć do wcześniejszego, nagrodzonego w Wenecji filmu Sokurowa Faust (Фaycm, 2011), a także takich znanych obrazów jak Amelia (Le fabuleux destin d'Amélie Poulain, 2001) czy Harry Potter i Ksiązę Pótkrwi (Harry Potter and the Half-Blood Prince, 2009).

Jednak najwięcej paraleli krytycy dostrzegają między filmami Rosyjska arka i Frankofonia. Wspomniany wyżej Dolin zwraca m.in. uwagę na występujący w obu obrazach motyw statku, podkreślając, że w ostatnich kadrach filmu z 2002 roku, będącego wizytówką Sokurowa, Ermitaż przedstawiony jest jako gigantyczny statek, przypominający zarówno biblijną arkę Noego, jak i Titanica. Również we Frankofonii przewija się motyw statku, a nawet zbliżającej się katastrofy morskiej. Motyw tonięcia pojawia się nie tylko w tle rozmów Sokurowa z kapitanem Dirkiem, przewożącym na statku ewakuowane dzieła sztuki, ale także poprzez odniesienia do obrazu Tratwa Meduzy (1818-1819) francuskiego mistrza pędzla Théodore'a Géricaulta. Tratwa Meduzy obok Mona Lisy (1503-1507) to jeden z najbardziej znanych obrazów z kolekcji Luwru, która na czas wojny została przetransportowana do innych, bardziej bezpiecznych miejsc, poza strefą okupacyjną. Dla Sokurowa ważne, symboliczne wręcz znaczenie ma tematyka obrazu Géricaulta. Utrwala on fakt za- 
tonięcia fregaty Meduza u wybrzeży Afryki w 1816 roku. Na pokładzie było ponad 150 pasażerów pozostawionych na pastwę losu przez załogę uciekającą z tonącego statku. W tej sytuacji pasażerowie zbudowali tratwę, ale kiedy po 13 dniach udało się dotrzeć do rozbitków, okazało się, że przy życiu pozostało jedynie 15 osób. Ważne przy tym jest, że po tych tragicznych wydarzeniach udało się doprowadzić do procesu sądowego, w którym osądzony został kapitan.

Nie ma wątpliwości, że chociaż Frankofonia zogniskowana jest wokół historii wojennej Luwru, Paryża oraz Francji, to dla rosyjskiego reżysera jest ona również pretekstem, by powrócić do wydarzeń, których z różnych względów nie mógł poruszyć szerzej w filmie Rosyjska arka. Chodzi nie tyle o sam Ermitaż, ale o sytuację oblężonego Leningradu i jego mieszkańców, pozostawionych właśnie podczas toczącej się wokół wojny na pastwę losu. Aluzje do rozbitków z obrazu Géricaulta są aż nadto czytelne. Leningradczycy, podobnie jak pasażerowie Meduzy, zostali pozostawieni sami sobie, co w konsekwencji doprowadziło do ich zdziesiątkowania. Jedyna różnica polega na tym, że odpowiedzialni za tragedię leningradzką właściwie nie ponieśli kary. We Frankofonii Sokurow powraca zatem do bolesnych tematów oblężenia, odkrywa luki, rany pamięci i blizny po traumie (Assmann 87), wykorzystując podobieństwa między francuskim i rosyjskim muzeum.

Co ciekawe, reżyser pomija właściwie oczywiste analogie między wojennymi dziejami Luwru i Ermitażu, milczy na temat udanej ewakuacji dzieł z muzeum w ówczesnym Leningradzie, nie wspomina również w kontekście osoby Jacquesa Jaujarda (jednego z dwóch głównych bohaterów Frankofonii, dyrektora Luwru) o postaci Josifa Orbelego, chociaż byłby to ciekawy punkt zaczepienia. Orbeli, z pochodzenia Ormianin, zarządzający Ermitażem w latach 1934-1951, nie tylko stał na czele grupy przeprowadzającej ewakuację kolekcji muzealnych przed zamknięciem pierścienia blokady, ale wsławił się tym, że wydał zarządzenie o pozostawieniu pustych ram obrazów dokładnie w tych miejscach, w których wisiały ocalone dzieła, co znacznie ułatwiło odtworzenie ekspozycji już po wojnie. $\mathrm{Na}$ motyw pustych ram natrafiamy w epizodzie dotyczącym oblężenia Leningradu we wcześniejszym filmie, czyli w Rosyjskiej arce. Rozpoczyna się on od sceny z przechodzącymi za plecami markiza de Coustine’a żołnierzami i odgłosu przelatującego samolotu. Następnie, mimo protestów narratora, czyli, podobnie jak we Frankofonii, samego Sokurowa, markiz otwiera drzwi, za którymi, jak można by sądzić, znajduje się magazyn i jakaś nieuporządkowana, niewykorzystana część ekspozycji, czekająca jakby na odkrycie. Tak naprawdę są to właśnie stosy pustych ram. Uwagę zwracają ponadto nieszczelne okna i dziwny człowiek, który w ukryciu zbija trumnę. Widząc nieproszonego gościa, nieznajomy zrywa się i wypędza go z komnaty. Polina Barskowa - jedna z najbardziej znanych badaczek blokady - uważa ten epizod za symboliczny, wskazuje, że za drzwiami znajduje się ukryta przed ludzkim wzrokiem sala - sala pamięci o tragicznym 
wydarzeniu, do której właściwie nikt poza markizem nie zagląda (Barskova, źródło elektroniczne). Głos narratora informuje nas jedynie cicho o smutnej historii XX wieku i ofiarach oblężenia, podkreślając, że było ich ponad milion. Chociaż jest to zaledwie epizod, to jednak wyczuwa się w nim niezwykłe napięcie emocjonalne, wyraźnie kontrastujące z barwną opowieścią o świetności miasta. To taki moment zawieszenia, dysonansu, dzięki któremu Sokurow po mistrzowsku osiągnął zamierzony cel, rozbijając z premedytacją odświętny nastrój i spójność narracji. Wspomniany wyżej dyrektor Orbeli pojawia się natomiast w Rosyjskiej arce w towarzystwie dwóch innych dyrektorów Ermitażu (tj. ojca Borisa i syna Michaiła Piotrowskich). Warto zaznaczyć, że młodszy Piotrowski to ten sam dyrektor, który zezwolił na zamknięcie Ermitażu dla zwiedzających na czas kręcenia zdjęć do filmu Rosyjska arka przez Sokurowa, co miało miejsce 23 grudnia 2001 roku, a w filmie zagrał samego siebie.

Brak paraleli w obrębie wojennych losów muzeów w analizowanych filmach wywołany jest zapewne hierarchią ważności poruszanych tematów i tym, że głównym bohaterem pozostaje tu paryskie muzeum. Kapitulacja Francji i fakt, że Paryż pozostawał podczas wojny miastem otwartym, gdzie toczyło się w miarę normalne życie, stanowi jednak pretekst do zadania pytania o możliwość poddania Leningradu w celu zmniejszenia liczby ofiar oblężenia. Poza tym, jak podkreśla krytyk filmowy Dolin, Luwr był jednym ze sponsorów filmu Sokurowa, a zatem eksponowanie dziejów wojennych Ermitażu mogłoby przecież zostać odczytane jako próba poruszania zagadnień z kręgu pamięci rywalizującej (Rothberg 15). Już zupełnie na marginesie warto zaznaczyć, że dyrekcja muzeum Luwru, oczarowana - podobnie jak władze innych światowych muzeów - koncepcją filmu o Ermitażu, nie była jednak zachwycona ani scenariuszem Frankofonii, ani finalnym efektem. I nie chodziło przy tym o inne środki wyrazu, ale o to, że rosyjski reżyser odnosił się do trudnych, niewygodnych dla Francuzów faktów z czasów II wojny światowej, co poskutkowało nieobecnością tego obrazu na festiwalu w Cannes (Dolin, źródło elektroniczne).

Dla Sokurowa - reżysera, ale i historyka - casus francuski stanowi ciekawy rodzaj interakcji czy też, w odniesieniu do koncepcji Astrid Erll, typ „sygnału wywołującego”, z którego wynika „wybór określonej wersji przeszłości z nim skojarzonej” (Tabaszewska 2013: 342). To jednak nie przeszkadzało reżyserowi, nawiązując do słów Stevena Katza, akcentować specyfikę blokady, różniącą się diametralnie od „każdego przypadku uznanego za porównywalny” (Rothberg 23):

Ленинградская трагедия - я бы так назвал блокаду Ленинграда - это глубочайшая человеческая беда. Это кратер, не сопоставимый по своим измерениям ни с чем, что происходило во время Второй мировой войны. Ни с чем! ("Vse fil'my o vojne - bol'šâ lož’”, źródło elektroniczne). 
Sokurow podkreśla, że oblężenie Leningradu, choć uchodzi za niezmiernie istotne wydarzenie w dziejach II wojny światowej, jest wciąż za mało rozpoznawalnym doświadczeniem granicznym, usuniętym na margines nie tylko historii powszechnej. I w tym znaczeniu wojenne losy Luwru są polem konfrontacji doświadczeń, odesłań, zapożyczeń, kontekstów. Dlatego, oprócz wspomnianej wyżej koncepcji Erll, strategia Sokurowa przywodzi na myśl inne projekty, a mianowicie koncept pamięci dialogicznej Assmann, a także model pamięci wielokierunkowej Michaela Rothberga. Pomaga on bowiem przesunąć wektor myślenia z obszaru współzawodnictwa, czy też podkreślania wyjątkowości danego wydarzenia historycznego i, co za tym idzie, odwracania uwagi od podobnych historycznych tragedii, w stronę podjęcia próby wypracowania właściwego miejsca i statusu zepchniętych na margines zdarzeń, a także zderzenia aktów trudnego pamiętania i zmierzenia się z nimi.

Poruszony we Frankofonii między wierszami problem niedoszłej kapitulacji miasta nad Newą, stanowiący ważną część traumatycznego dziedzictwa przeszłości i powracający w wielu dyskusjach, nurtował reżysera już wcześniej. W 2009 roku w wywiadzie z okazji premiery dokumentu Czytając , Księge blokady” Sokurow nawiązał do wojennej historii Paryża, do jego okupacyjnego statusu:

[...] я всегда вспоминаю тот самый, европейский, вариант общения правительства и общества с противником. Вот французы открыли ворота Парижа врагу. Я не хочу сейчас говорить о причинах, почему они это сделали. Но это было совершенно невозможно, невероятно для жителей Ленинграда! При этом я часто возвращаюсь к одной мысли: ленинградские жертвы непомерно высоки. Ни один город не стоит таких потерь. Здесь я согласен с Виктором Астафьевым, который об этом много думал и говорил, а он солдат той войны. Первый раз я услышал его точку зрения о том, что надо было сдать Ленинград, на одной из первых встреч советской интеллигенции с Горбачевым, нас всех потрясли слова Астафьева о непомерности, о неадекватности жертв блокады ( "Vse fil'my o vojne bol'šâ lož',", źródło elektroniczne).

Frankofonia to zatem kolejna okazja, by przypomnieć światu o bolesnej ranie zadanej Leningradowi i leningradczykom nie tylko przez Niemców, a przy tym wskazać na zbyt wysoką cenę ocalenia. Paryż jako miasto otwarte nie poniósł właściwie żadnych strat, zarówno jeśli chodzi o materialne dziedzictwo, jak i ludność cywilną. W tym samym czasie Leningrad, nękany ostrzałami i bombardowaniami, przedstawiał żałosny i przerażający widok - to miasto ruin i ciał wygłodzonych i wyziębionych mieszkańców. Z komentarzy Sokurowa-narratora można wysnuć wniosek, że winny zaistniałej katastrofie humanitarnej jest splot różnych, niekorzystnych okoliczności, z których, zdaniem reżysera, oprócz wewnętrznej niezgody władz na poddanie miasta, z całą pewnością najważniejsze było odmienne podejście Niemców do okupacji zachodnich (tj. francuskich) i wschodnich ziem. Słychać tu w głosie narratora żal, ale i pytanie, wątpliwość dotyczącą różnych lo- 
sów dwóch miast i dwóch muzeów. Potwierdzenie tego innego podejścia możemy odnaleźć w dalszych działaniach dyrektora muzeum, który brał udział w dokumentowaniu strat dokonanych przez faszystów nie tylko w Leningradzie, ale również w takich obiektach, jak pałace w Pawłowsku, Puszkinie i Peterhofie. O ile w filmie Frankofonia dominuje temat symbolicznego kompromisu, zawartego przez przedstawicieli dwóch wrogich obozów, dla których jednak najważniejsze znaczenie ma dobro sztuki, o tyle w kontekście opowieści leningradzkiej podkreślona jest właśnie zła wola i zadziwiający brak wrażliwości wyczulonych na piękno Niemców w odniesieniu do dziedzictwa materialnego i kulturowego północnej stolicy i okolicznych pałaców. Przekonujemy się o tym również wtedy, gdy czytamy o udziale Orbelego w charakterze świadka oskarżenia podczas toczącego się już po wojnie procesu norymberskiego i jego skrupulatnych zeznaniach na temat bomb zrzucanych na miasto, zniszczeń w obrębie zabytków, w tym szczególnie Ermitażu. Świadomość, że Leningrad miał zniknąć z powierzchni ziemi, jest porażająca, szczególnie w zestawieniu z podejściem Niemców do dziedzictwa narodowego Francji. Nic dziwnego, że powracają pytania, zadawane wielokrotnie od czasu wojny, jak możliwe jest istnienie takiego dysonansu między umiłowaniem sztuki i kultury przez Niemców oraz zbrodniami przeciwko ludzkości i zagładą materialnego dziedzictwa wielu narodów. Wątek ten pojawia się choćby w rozmowie Siergieja Uwarowa z dyrektorem Ermitażu, Piotrowskim, który bardzo radykalnie wypowiada się na ten temat:

Наследники Гёте, Шиллера и Канта! [...] когда у нас была война, оказалось, что те немцы, которые пришли к нам, сильно непохожи на тех, к которым мы привыкли по литературе. Оккупанты Парижа были порафинированнее, и у них была другая игра. [...] Всем известно, что война в Европе велась совершенно по-другому, и там город брали, чтобы для себя сохранить, а здесь - чтобы уничтожить. Там они приходили и думали: вроде французы и недолюди, а вроде и ничего, европейцы. А здесь их восприятие было однозначным: все - животные, города уничтожить, всех истребить... (Uvarov 207-208).

A przecież zarówno w Luwrze, jak i w Ermitażu znajdziemy dzieła największych mistrzów. Te dwa muzea, zdaniem Sokurowa, łączy wiele:

[...] глубинная связь с Эрмитажем очевидна. У Лувра нет другого соразмерного ему соперника-собрата. Они произрастали друг из друга: не было бы Лувра - не было бы и Эрмитажа. Бывая в русских собраниях живописи, я чувствую связь с Лувром. На существовании Эрмитажа высвечиваются многие проблемы Лувра как культурной сущности. Эта сущность выше государства, даже выше народа (Kičin, źródło elektroniczne).

Co ciekawe, związek Sokurowa z Ermitażem to nie tylko obraz Rosyjska arka, będący widowiskową, efektowną, barwną opowieścią o historii Petersburga, zrealizowaną w przestrzeni muzeum, która wyjątkowo, zdaniem reżysera, sprzyja 
uruchamianiu wyobraźni i łatwości przenoszenia się w inne epoki, z ich bogactwem strojów, dodatków, atrybutów. Już wcześniej w twórczości tego artysty pojawił się film wyreżyserowany na zlecenie dyrekcji w siedzibie muzeum. Mowa o dokumencie Robert. Szczęśliwe życie (Робер. Счастливая жизнь) z 1996 roku. W nim również spotykamy się z kontemplacją dzieł, tym razem pędzla XVIII-wiecznego francuskiego artysty Huberta Roberta, zwanego Robertem od Ruin. Lejtmotywem jego twórczości pozostają bowiem pejzaże, na których malarz utrwala obrazy pozostałości po antycznych budowlach Francji i Włoch. Bliski ponadto jest mu motyw kataklizmu, przewijającego się w jego twórczości w postaci pożaru (obraz pod takim właśnie tytułem znajduje się zresztą w kolekcji Ermitażu) oraz niszczenia i rozbiórki budynków paryskich z czasów rewolucji francuskiej. Pozwala to mówić o ciekawym reportażu malarskim utrwalającym tamte czasy (Malarstwo ruin..., źródło elektroniczne), a w kontekście zainteresowań Sokurowa także o nieoczywistym, tylko na pierwszy rzut oka, wyborze bohatera filmu, którego dzieła możemy podziwiać zarówno w Luwrze, jak i w Ermitażu. Nie bez znaczenia wreszcie są i czasy współczesne francuskiemu artyście, tj. burzliwy okres rewolucji francuskiej, w której niezmiernie ważną, przełomową rolę odegrał przecież jeden z bohaterów Frankofonii - Napoleon Bonaparte. Po raz kolejny zatem w twórczości Sokurowa możemy odnaleźć różne, na pozór odległe motywy, wątki, które jednak, jak się okazuje, pojawiają się nieprzypadkowo. Filmowy kolaż literatury, sztuki, historii i muzyki ma za zadanie uświadomić odbiorcy podobieństwo mechanizmów zachowań i pewnych nieuchronnych prawidłowości w przypadku zdarzeń odległych czasowo i kulturowo, a także zawartą w nich cenną przestrogę i, co za tym idzie, użyteczność płynącą z przechowywania ich w pamięci.

I wreszcie last but not least „epizod ermitażowy” w twórczości Sokurowa, czyli jego udział w weneckim biennale, na którym wraz z innym artystą, inscenizatorem teatralnym Aleksandrem Szyszkinem-Chokusajem, na zlecenie Ermitażu, tj. kuratora wystawy, tworzył multigatunkowy projekt w pawilonie rosyjskim, co po raz kolejny potwierdziło wszechstronność reżysera, jego niezwykłą intuicję twórczą, przejawiającą się w umiejętnie prowadzonym dialogu współczesności z klasyką, sztuki z innymi dziedzinami życia. W roli głównej eksperymentalnej prezentacji Sokurowa ponownie pojawiają się obrazy, tym razem płótna znane szerszej publiczności. Mowa o obrazach Rembrandta Powrót syna marnotrawnego (1661-1669) oraz Portret staruszki (1631), a także dziele Iwana Kramskoja Chrystus na pustyni (1872). Wraz z innymi elementami ekspozycji, takimi jak rzeźby wykonane m.in. przez Władimira Brodarskiego czy nagrania wideo, dzieła malarskie służą jako niezwykłe memento dla współczesnego świata rozdzieranego różnymi konfliktami, w tym szczególnie konfliktami militarnymi. Receptą ma być powrót do korzeni - do wartości chrześcijańskich (stąd nazwa całego projektu 
Łk 15, 11-32 - skrót odsyłający do fragmentu Pisma Świętego, gdzie znajdziemy przypowieść o synu marnotrawnym), ale również wskazówek pozostawionych przez wielkich mistrzów malarstwa.

To, co przychodzi do głowy w związku z wykorzystanymi przez Sokurowa podczas prezentacji w Wenecji obrazami, to myśl, że nieustannie próbuje on przypominać współczesnym ludziom o zaletach istnienia kanonu. Dzięki niemu bowiem możliwe jest zachowanie ciągłości kulturowej i kształtowanie pamięci więcej niż jednego pokolenia (Tabaszewska 2013: 344). Nie należy jednak zapominać, że na tworzenie kanonu wpływ może mieć obowiązująca w danym okresie polityka pamięci i że z jego politycznością można walczyć jedynie poprzez próbę wprowadzenia zmian, aktualizacji, redefinicji, co nierzadko oznacza (powtórne) osadzenie w kontekście tradycji. Słowa te z powodzeniem mogą być odniesione do reprezentatywnych tekstów kultury, służących utrwalaniu pamięci o oblężeniu, której zdecydowanym orędownikiem pozostaje i sam Sokurow. (Za)istnienie i uzupełnianie kanonu ma szczególne znaczenie w kontekście zmieniającej się retoryki pamięci o tym wydarzeniu. I trzeba przyznać, że dwie pierwsze dekady XXI wieku okazują się sprzyjającym czasem dla rewizji tekstów, filmów o blokadzie i zawartego w nich przekazu. Uwagę zwraca ponadto coraz bardziej różnorodne i wielowarstwowe spektrum form służących rozpowszechnianiu pamięci. To już nie tylko filmy, teksty poetyckie, prozatorskie i naukowe, ale komiksy, opracowania dla dzieci (Dolin, Ûzefovič, źródło elektroniczne).

W tym miejscu warto natomiast zastanowić się, co decyduje o przynależności do kanonu w przypadku blokady Leningradu. Na pewno będą to wszelkie próby wykorzystujące dokumenty archiwalne, często widziane, odczytane w nowym świetle. Niemniej ważne są materiały z kręgu historii rodzinnych, szczególnie istotne wobec coraz większego oddalenia czasowego od wydarzeń blokady, powiązanego „ze zjawiskiem odchodzenia [świadków - dop. B.P.] i koniecznością ukształtowania pamięci o Wydarzeniu bez ich obecności" (Bilczewski 61). Istotne są wreszcie wysiłki, by wpisać blokadę w krąg innych wydarzeń o charakterze granicznym, co dzieje się dzięki dostrzeżonym analogiom, paralelom, ale i mającym charakter zabiegów uniwersalizujących odwołaniom do wcześniejszych dzieł. Pamięć o danym wydarzeniu utrwala się wreszcie dzięki powtarzalności pewnych motywów, rekwizytów, przedmiotów o symbolicznym wręcz znaczeniu, jak np. puste ramy w Ermitażu. Dla potwierdzenia dobrze będzie odwołać się po raz kolejny do koncepcji Astrid Erll, wyróżniającej „trzy mechanizmy, dzięki którym [...] re-prezentacje pamięci służą budowaniu lub przepracowywaniu poszczególnych form pamięci kulturowej. Owe mechanizmy to kondensacja, narracja oraz osadzenie w kontekście tradycji danego gatunku" (Tabaszewska 2013: 346). Dla nas spośród nich szczególne znaczenie ma narracyjność kształtująca „zarówno sposób pamiętania [...], jak i kanoniczny zasób wspomnień dla danego 
społeczeństwa" (Tabaszewska 2013: 346). Dokonuje tego, wykorzystując m.in. użyteczne klisze narracyjne i pamięciowe, aktywowane podczas czytania różnych tekstów kulturowych.

Egzemplifikacją koncepcji Erll w odniesieniu do narracji o oblężeniu i roli muzeum z ponownym wykorzystaniem motywu pustych ram i odniesień do twórczości Rembrandta może służyć zbiór prozy Żywe obrazy (Живые картины) Poliny Barskowej, opublikowany w 2014 roku i nagrodzony w 2015 roku Nagrodą Literacką im. Andrieja Biełego, a szczególnie stanowiąca postscriptum sztuka pod tym samym tytułem. Wspomniana wyżej badaczka, znana z przełomowych, ważnych tekstów o blokadzie, bazujących na archiwaliach, występuje tu w roli pisarki snującej opowieść o artystach, przedstawicielach rosyjskiej sztuki i nauki, pozostających w oblężonym mieście i starających się ocalić choćby namiastkę normalnego życia. W myśl słów wypowiedzianych przez obecnego dyrektora Ermitażu Michaiła Piotrowskiego, że muzeum jest stworzone nie tyle po to, by pokazywać, ile by chronić, ocalać, Barskowa nawiązuje do wojennej odsłony Ermitażu, a szczególnie pierwszej zimy w oblężeniu, kiedy po udanej ewakuacji dzieł muzeum stało się realnym schronieniem dla wielu ludzi, przede wszystkim pracowników. W jego piwnicach urządzono schrony i zorganizowano w miarę sprzyjające warunki nie tylko do przeżycia, ale również twórczej pracy.

Bohaterami sztuki są trzydziestosiedmioletnia Antonina (Totia) oraz dwudziestopięcioletni Moisiej, dla których pierwowzorami byli historyk sztuki Antonina Izergina oraz architekt, rysownik i ilustrator Moisiej Wakser. Izergina to jedna z ciekawszych postaci związanych z Ermitażem. Urodzona w 1906 roku w Kuokkali, pracę w muzeum rozpoczęła w 1930 roku. Najpierw była zatrudniona jako przewodniczka, a później pracownik naukowy. Od 1937 roku kierowała oddziałem zachodnioeuropejskiej sztuki XIX i pierwszej połowy XX wieku. Jej specjalnością było malarstwo niemieckie oraz francuskie. W lutym 1942 roku Izergina wraz z innymi pracownikami muzeum została ewakuowana do Ałma-Aty i pracowała tam jako instruktorka alpinizmu, który oprócz malarstwa i rzeźby był jej drugą, ogromną pasją. Po powrocie do Leningradu aktywnie włączyła się w prace nad odtworzeniem ekspozycji Ermitażu, a w 1946 roku została żoną ówczesnego dyrektora muzeum Josifa Orbelego. W tym samym roku urodził im się syn Dmitrij. W Ermitażu Izergina pracowała praktycznie do końca życia, tj. do 1969 roku. Z kolei Wakser (ur. w 1916 roku w Baku) nie tylko nie dożył końca blokady, ale nie doczekał nawet ewakuacji pracowników przeprowadzonej w lutym 1942 roku. Przyczyną jego śmierci była oczywiście dystrofia. Wakser był utalentowanym rysownikiem, ilustratorem książek i czasopism dziecięcych. W 2001 roku w Izraelu, dzięki staraniom młodszego brata Ariego, ukazała się książka Wakserilia, na którą oprócz wspomnień i fotografii rodzinnych, a także listów i zapisków Moisieja złożyły się ilustracje m.in. do książki Obłomow (Обломов, 1859) Iwana Gonczaro- 
wa, a także te przygotowywane na zlecenie wydawnictw mińskich, przeznaczone do, nieopublikowanych niestety, wydań Baśni tysiąca i jednej nocy oraz Opowieści pótnocnеј (Северная повесть, 1938) Konstantego Paustowskiego, plakaty i prace dla projektu „Okna TASS” (Pawletko 67-71), szkice z historii architektury czy ilustrowana opowieść o tytułowej Wakserilii. W 1940 roku, już po poznaniu Antoniny, jako stały bywalec Ermitażu, Wakser stworzył serię rysunków Nasz Ermitaż (Нам Эрмитаж), w której z dużą dozą humoru, a czasami wręcz w karykaturalny sposób portretował odwiedzających muzeum, reprezentujących różne warstwy społeczne. Waksera ciekawiło, w jak odmienny sposób ludzie odbierają sztukę, jak różnie się zachowują i reagują, np. na uwagi pracowników, jaki jest cel ich wizyty, na co zwracają uwagę. Niektóre prace to jakby scenki rodzajowe, widziane okiem „ukrytej kamery”, opatrzone zabawnymi komentarzami; one również znalazły się w wydanej przez brata książce (Vakser, źródło elektroniczne).

Sztuka Barskowej uzmysławia, że w oblężonym mieście ludzie nie tylko umierają, są w obliczu głodu bezwzględni wobec innych, walcząc o życie, ale także kochają i upominają się o prawo do swojego kruchego szczęścia oraz ocalenia choćby namiastki piękna w niepięknych czasach. Autorka, opierając się na dokumentach archiwalnych - fragmentach dzienników, wspomnień, listów, ale i na intertekstualnych nawiązaniach do różnorodnych tekstów kultury, m.in. Królowej śniegu (1844) Hansa Christiana Andersena, tworzy utwór, który określa mianem dokumentu-bajki. Ważną rolę odgrywają w sztuce, co oczywiste, realia i symbole oblężenia, słowa klucze, utrwalone już wcześniej w innych reprezentatywnych utworach poświęconych blokadzie. Spośród nich na szczególną uwagę zasługują właśnie puste ramy. Motyw ten stał się zresztą bezpośrednią inspiracją do powstania sztuki, a potem spektaklu teatralnego, zrealizowanego w 2016 roku przez moskiewski Teatr Nacji. Niezwykłe jest przecież to, że, jak zwrócił uwagę reżyser sztuki Wiktor Ałfierow, puste ramy przetrwały cały okres oblężenia, mimo iż mogły zostać spalone przez zdesperowanych pracowników. I właśnie wokół pustych ram i ludzi, którzy w wymarłym, budzącym skojarzenie z jaskinią muzeum znaleźli schronienie, zasadza się szczególny sens sztuki. W jej tytule pobrzmiewa wieloznaczność. $Z$ jednej strony mowa o skojarzeniach związanych z oblężeniem. Życie w Ermitażu podczas blokady tli się dzięki ludziom. To oni wypełniają ogołoconą, martwą przestrzeń i napełniają ją sensem, przemawiając w imieniu ewakuowanych mistrzów. To dzięki nim, ich rozmowom artyści i obrazy żyją w pamięci oblężonych. Symboliczna jest w tym kontekście kreacja trzeciej bohaterki sztuki, siedemdziesięcioletniej przewodniczki po Ermitażu Anny Pawłowny, która stając przed pustymi ramami, opowiada z pamięci, co przedstawione jest na nieobecnych płótnach (Pawletko 166). Z drugiej strony tytuł sztuki odsyła też do popularnej, zwłaszcza w XIX wieku, formy aktywności (od)twórczej. Mowa o rodzaju pantomimy, której uczestnicy zastygają w pozach bohaterów popularnych obrazów, pozując na tle pustych ram. W sztuce 
Barskowej są to obrazy Rembrandta. Ich „re-konstrukcja”, dokonana przez Annę Pawłowną, Moisieja i Totię zakłada nie tylko pamięć o ewakuowanych dziełach, sprawdzenie stanu swojej wiedzy o nich, ale przede wszystkim podjęcie próby utożsamienia się z daną postacią, konfrontacji z jej emocjami, przeprowadzonej w ekstremalnych warunkach oblężenia, co oznacza tak naprawdę chęć wyrwania się choć na chwilę z martwej, pustej przestrzeni. Bohaterka sztuki, dla której pierwowzorem była Antonina Izergina, skonfrontowana zostaje z bohaterką dzieła Rembrandta $\mathrm{Da}$ nae (1636).

Zarówno Barskowa, jak i Sokurow zapewnili sobie trwałe miejsce w kanonie tekstów kulturowych o oblężeniu, stanowiących inspirację i punkt odniesienia dla innych twórców, świadomie wykraczając poza „bardzo uproszczony schemat pamięci bezpiecznej dla tworzenia tożsamości narodowej" (Tabaszewska 2016: 375). Stąd pojawiające się w ich twórczości zagadnienia winy i wstydu czy powrót do innych tematów tabu w celu ich przepracowania. Łączy ich ponadto fakt, że (współ)tworząc, inicjując różnorodne projekty, wpisują się w obszar szeroko rozumianej postpamięci, tak naprawdę bowiem nikt z ich rodziny nie doświadczył bezpośrednio piętna oblężenia. A jednak bez cienia wątpliwości można ich określić mianem „depozytariuszy pamięci” (Tomczok 9) o blokadzie, będącej ważnym elementem ich tożsamości, przewijającym się w kolejnych podejmowanych inicjatywach. Nic dziwnego, że twórcy ci, dostrzegając zalety przemian i coraz większej różnorodności form i dyskursów pamiętania i upamiętniania blokady, $\mathrm{z}$ uwagą śledzą aktualne dyskusje na ten temat, nierzadko uczestniczą w nich bezpośrednio, szczególnie Sokurow, mieszkaniec Petersburga. O blokadzie mówi on nie tylko językiem filmu czy sztuki, ale świadomie zwraca się także w kierunku środków masowego przekazu, licząc na szerszy zasięg i większy krąg odbiorców. Znamienne bowiem dla dyskursu o oblężeniu zaczyna być to, że zmagać musimy się nie tylko z jego ciągłym upolitycznieniem, ale również banalizacją, komercjalizacją. Zdaniem reżysera, nie ma zgody na to, by oblężenie nagłaśniać medialnie za wszelką cenę, a szczególnie w popkulturze. Z oburzeniem twórca Czytając „Księgę blokady” zareagował chociażby na propozycję, aby tematem zajął się np. Steven Spielberg, co z pewnością przełożyłoby się na większą rozpoznawalność w świecie tego doświadczenia granicznego. Nie jest to, zdaniem twórcy Frankofonii, właściwa droga ani do godnego upamiętnienia blokady i jej ofiar, ani tym bardziej do wpisania tej ważnej nie tylko w skali miasta nad Newą katastrofy humanitarnej w obszar świadomości europejskiej i światowej. W ten sposób Sokurow, jako uznany w świecie przedstawiciel kinematografii rosyjskiej, upomina się, by przekaz o blokadzie oczyścić z manipulacji, nadużyć, przekłamań i uczynić go wreszcie polem pogłębionej empatii i refleksji nie tylko o przeszłości, ale przede wszystkim o przyszłości, kondycji współczesnego człowieka i znaczenia w jego życiu kultury i historii. 


\section{Bibliografia}

Ass, Kirill. Narušennoe molčanie. Web. 06.08.2019. https://seance.ru/blog/sokurov-blokada/.

Barskova, Polina. Nastalo vremâ vojti v komnatu blokady. Web. 12.08.2019. https://www.goethe.de/ $\mathrm{ins} / \mathrm{ru} / \mathrm{ru} / \mathrm{kul} / \mathrm{arc} / 2017 / \mathrm{blockade} / 20915260 . \mathrm{html}$.

Dolin, Anton. „Frankofoniâ” Aleksandra Sokurova: korablekrušenie. Web. 03.09.2019. https://daily.afisha.ru/archive/vozduh/cinema/frankofoniya-aleksandra-sokurova-korablekrushenie/.

Dolin, Anton, Galina Ûzefovič. Rovno 75 let nazad zakončilas' blokada Leningrada. Web. 23.08.2019. https://meduza.io/slides/rovno-75-let-nazad-zakonchilas-blokada-leningrada-votdevyat-filmov-i-knig-o-ney-kotorye-stoit-posmotret-i-prochitat.

Kantor, Ûliâ. „Podvig svoj ežednevnyj vy soveršali dostojno i prosto”. Rossijskaâ gazeta, 9, 2013. Web. 31.08.2019. https://rg.ru/2013/01/18/blokada.html.

Kičin, Valerij. „Uroki Bonaparta. Aleksandr Sokurov: o Frankofonii i o roli muzeev v našej istorii”. Rossijskâ̂ gazeta, 196, 2015. Web. 04.09.2019. https://rg.ru/2015/09/03/sokurov.html.

Koreckij, Vasilij. Aleksandr Sokurov: Napoleon - ubijca. No vse zabyto. Â uveren, čto is Gitlerom budet to že samoe. Web. 03.09.2019. http://os.colta.ru/cinema/events/details/34403/page2/.

Uvarov, Sergej. Intonaciâ. Aleksandr Sokurov. Moskva, Novoe literaturnoe obozrenie, 2019.

Vakser, Ari. Vakseril'â. Web. 22.08.2019. https://people.cs.clemson.edu/ isafro/vakserilya/.

„Vse fil'my o vojne - bol'šaâ lož"'. Ogonëk, 14, 2009. Web. 06.09.2019. https://www.kommersant. $\mathrm{ru} / \mathrm{doc} / 1217259$.

Beumers, Birgit, Nancy Condee, red. The Cinema of Alexander Sokurov. London, I.B. Tauris, 2011.

Bilczewski, Tomasz. „Trauma, translacja, transmisja w perspektywie postpamięci. Od literatury do epigenetyki”. Od pamięci biodziedzicznej do postpamięci. Red. Teresa Szostek, Roma Sendyka, Ryszard Nycz. Warszawa, Wydawnictwo IBL PAN, 2013, s. 40-62.

Malarstwo ruin, wykopalisk, katastrof i więzień. Wykład prof. Andrzeja Pieńkosa. Web. 05.09.2019. https://www.lazienki-krolewskie.pl/pl/wydarzenia/malarstwo-ruin-wykopalisk-katastrof-i-wiezien-o-przyjemnych.

Pawletko, Beata. Blokada Leningradu i jej reprezentacje w świetle innych doświadczeń granicznych. Katowice, „Śląsk” i SIW, 2016.

Rothberg, Michael. Pamięć wielokierunkowa. Pamiętanie Zagłady w epoce dekolonizacji. Przeł. Katarzyna Bojarska. Warszawa, Wydawnictwo IBL PAN, 2015.

Saryusz-Wolska, Magdalena. Spotkania czasu z miejscem. Studia o pamięci i miastach. Warszawa, Wydawnictwa Uniwersytetu Warszawskiego, 2011.

Skarga, Barbara. Ślad i obecność. Warszawa, Wydawnictwo Naukowe PWN, 2002.

Syska, Rafał. Filmowy neomodernizm. Kraków, Wydawnictwo Avalon, 2014.

Syska, Rafał. „Nostalgia za Tarkowskim. Kino Carlosa Reygadasa i Aleksandra Sokurowa”. Strefa filmu. Kino Andrieja Tarkowskiego. Red. Iwona Anna NDiaye, Marek Sokołowski. Toruń, Wydawnictwo Adam Marszałek, 2013, s. 357-378.

Tabaszewska, Justyna. „Klisze i prześwietlenia. Braki i naddatki polskiej pamięci”. Teksty Drugie, 6, 2016, s. 375-386.

Tabaszewska, Justyna. „Literatura o pamięci, pamięć w literaturze czy pamięć literatury?”. Od pamięci biodziedzicznej do postpamięci. Red. Teresa Szostek, Roma Sendyka, Ryszard Nycz. Warszawa, Wydawnictwo IBL PAN, 2013, s. 341-351.

Tomczok, Marta. Czyja dzisiaj jest Zagłada? Retoryka - ideologia - popkultura. Katowice, Instytut Badań Literackich PAN i UŚ, 2017.

Wojnicka, Joanna. „Kino sowieckie i rosyjskie”. Kino końca wieku. Red. Tadeusz Lubelski, Iwona Sowińska, Rafał Syska. Kraków, Universitas, 2019, s. 373-421. 
